\title{
The Challenges of Government Public Relations and Abuse of Power over Indonesia
}

\author{
Suwandi Sumartias ${ }^{1}$, Nurtyasih Wibawanti Ratna Amina ${ }^{2}$ \\ \{suwandi.sumartias@unpad.ac.id $\left.{ }^{1}\right\}$ \\ ${ }^{1}$ Faculty of Communication Sciences, Universitas Padjadjaran, Indonesia \\ ${ }^{2}$ Stikosa Surabaya, Indonesia
}

\begin{abstract}
The article is opinion based on literature study. Era of globalization, democratization and transparency of information has significantly changed the social order, economic, politic and culture in the world, including Indonesia. Indonesia face the fundamental problem and crucial that the massive corruption and nepotism as a form of abuse of power in the government bureaucracy, especially in the executive, legislative and judicial. Currently, the arrested of Akil Mochtar as Chairman of Indonesia's Constitutional Court, October 3, 2013 by the Corruption Eradication Commission (Komisi Pemberantasan Korupsi) for alleged bribery in regional elections in Indonesia, being a massive print media coverage and social media, also in the citizens. Akil Mochtar was previously arrested because of alleged corruption in Central Kalimantan and Lebak regional elections. KPK also named Functional Group Party (Golkar) politician Chairun Nisa and brother of Banten's Governor Tubagus Chairi Wardana. Indonesia became the almost corrupt of 16 countries in Asia Pacific based on survey Political and Economic Risk Consultancy, Ltd. (2010-2013). Similarly, the practice of dynastic politics in Banten's Governor Ratu Atut, further confirms that corruption and nepotism became acute and habituation misunderstood common sense. Public relations in government agencies should have a research function and counseled leaders in taking a variety of policies. Unfortunately, the function and the existence of public relations government is helpless, especially in maintaining the organization's image and reputation of a clean government corruption. Public relations officers even more confused if faces of various demands of citizens to public disclosure in accordance with Act No. 14 of 2008 about Public Information Disclosure.
\end{abstract}

Keyword: Government Public Relations; Officer, Clean Government; Corruption; Image and Reputation

\section{Introduction}

The new chief justice of Indonesia's Constitutional Court, which until now has enjoyed rare high public trust, has been arrested on suspicion of taking bribes worth more than $\$ 250,000$ to fix a case he was hearing. Akil Mochtar's arrest has raised anger about high-level corruption to a new pitch and the court's founding chief justice has called for the death sentence, which current law does not allow [1]. 
Indonesia as a developing country is not free from the influence of globalization and democratization incredible. One's effects that emerged since the 1998 political reform in that Soeharto's regime downfall of authoritarian rule for 32 years. Since then, the political liberties of citizens as widespread, that is marked by the 44 political parties contesting the 1999 general elections, that before the reform required to have 3 parties. The presence of multi-party democracy as a result, also have an impact on the behavior of public who have not grown for democracy. In the 2014 general election, the several parties that pass the verification Election Commission amounted to 12 political parties.

Both bureaucratic and grand corruption are present in Indonesia. Bureaucratic corruption is exacerbated by the country's weak administrative capacity, low salaries, and the lack of oversight. In this context, bureaucratic and administrative forms of corruption are widespread across all public services and agencies. For example, $15,4 \%$ of all companies interviewed in the 2012 Global Competitiveness Report consider corruption as the most severe problem affecting the business environment in Indonesia. Moreover, according to the World Bank \& IFC Enterprise survey, nearly $15 \%$ of the companies reported being expected to pay bribes to public officials to 'get things done' [2].

Are democracies less corrupt than other forms of government? The desire for re-election constrains the greed of politicians. The protection of civil liberties and free speech, which generally accompanies democratic elections, makes open and transparent government possible. In contrast, non-democratic states are especially susceptible to corrupt incentives because their rulers have the potential to organize government with few checks and balances [3].

Freedom of political parties and competition synonymous with the fight for race positions in the bureaucracy (government), starting from the post of president, minister to the lowest level regents or mayors (executive), members of parliament (legislative) and bureaucratic legal ( judicial). Unfortunately, democracy is run by the politicians was still tinged with a variety of fraudulent practices ranging from presidential election campaign, regional head and members of the parliament and council.

After 32 years of an authoritarian regime which ended in 1998 with the fall of General Suharto, Indonesia has undergone a successful transition from authoritarian rule to become one of the largest democracies in Asia and in the world. Since 1998, the government has introduced a range of economic and political reforms aimed at erasing the legacies of the old regime. Local governments have been empowered, the judiciary has been granted greater independence, and a national campaign against corruption has been initiated after corruption was acknowledged as a major problem affecting the Indonesian economy, politics, and foreign investments [4]. Nevertheless, the country continues to face several challenges with a deeply embedded patronage system and widespread corruption at all levels of government [2].

Various violations of the laws and regulations in the government bureaucracy increasingly acute, such as money politics, corruption and nepotism more massive and open in a variety of public and media. Practice of democracy is merely a crowd in the campaign and ballot alone. The essence of democracy, should provide quality of life changes; welfare and make peace, not domination of the political elite in the circles of power and bureaucracy. Democracy looks as demonstration.

Dobski and Gish [5] state in 'The political Crisis of Liberal Democracy': The legitimacy of the liberal democratic principle (to say nothing of its allure) rests on its claim to speak to and for 
human being as human beings rather than as citizens of any particular political community or nation-state. From the lofty perspective of liberal humanitarianism, national bodies politic which insist upon drawing and defending borders that separate and distinguish one people from another inevitably represent an unacceptable affront to human dignity.

The political legacy of previous regimes in which public resources were used to gain support of patronage networks continues to play a role in the political landscape of the country after democratization. Various forms of patronage and clientelism exist across the political system, as reflected by concessions and procurement processes being often awarded based on personal relations [2]. In addition, the increasing reliance on money for political campaigns has offered opportunities for political corruption and state capture, in particular at the local level [2].

Since the 1998 reform, Indonesia's citizens are faced with demands to reform the bureaucracy and public disclosure and transparency of the administration free of corruption. Practice of abuse of power by politicians and bureaucrats in government are increasingly open wide in a variety of media and general public. This situation has been shaping the image and reputation of the government institutions (bureaucracy) and the politicians really negative and make apathetic citizens. While, the existence of government public relations staff in the government bureaucracy as helpless to improve the image and reputation of the negative. Government public relations function has not been optimal and professional in carrying out the task, especially to improve, create, maintain a positive image and reputation of the institution

\section{Corruption: abuse of power}

Law of Republic Indonesia, No.21/2001 amendment to law No.31/1999 on Corruption Eradication, define corruption (article 3): "Anyone with the intention of enriching himself or other persons or a corporation, abusing the authority, the facilities or other means at their disposal due to rank or position in such a way that is detrimental to the finances of the state or the economy of the state...")

A concerted fight against corruption - in some cases defined synonymously with briberyseems to have broken out around the globe in many spheres of social life where it rears its head. Public awareness of, and tolerance for, corruption has seen a sea change over the past decade as information and expectations have caused people to expect more from their leaders. While much of the focus of the current struggle to reduce corruption is on making bribes more difficult to pay and accept, "corruption" involves much more than bribes [6].

Simon Butt, Anti-corruption reform in Indonesia. An Australian law academic focused on Indonesia sums up the challenge: "Corruption is so endemic within the justice system that the system is often referred to as the 'justice mafia'. In most types of cases, including corruption cases, police can be 'persuaded' to drop an investigation, lose important evidence, or charge a suspect with a lesser offence. In return for a bribe, prosecutors often drop a prosecution, present their case poorly at trial, or seek a lenient penalty ... The result is, in essence, immunity for those whose cases are handled by ordinary law-enforcement institutions and who are willing and able to bribe their way out of trouble" [7].

In the case of Indonesia, corruption in the country is likely to be facilitated by a number of factors, such as large amounts of public resources derived from natural resources, vested interests and politically connected networks, poorly paid civil servants, low regulatory quality, and weak 
judicial independence. In addition, local officials are given wide discretionary power and resources without proper accountability and enforcement mechanisms [8].

Law enforcement measures in Indonesia seemed stalled, because of many corrupt behavior by officials in Indonesia. Mahfud MD said "Almost all of the official corruption, bureaucracy because of law enforcement in Indonesia is still bad. Thus giving the opportunity for corruption officials. And ironically, none president can improve it, including President Susilo Bambang Yodoyono" [9].

Corruption in Indonesia is undoubtedly pervasive. The process of decentralisation that commenced in 2001 marked a period during which corruption encountered by international businesses - particularly those interacting with officials in poorly-governed districts - was exacerbated. Grand corruption scandals play a large role in Indonesian domestic politics, with political groups attempting to use such issues to undermine their political opponents. Recent corruption scandals attest that involvement in corruption does not need to be proven to be politically damaging. Corruption is so widespread and the legal system so easily manipulated that the Indonesian public cynically assumes that most allegations have at least some truth behind them [7].

Michael Johnston states under a modern democratic system, individuals choose their values and their rulers in conformity with those values. It is therefore understood that the rulers reflect the morality of the ruled. Definition of corruption, in this context, has come to be related to the behavior of the individual who has been chosen to rule or govern. This ruler is not expected to define morality - other than in designing the legal framework - but merely to act according to the established norms [6].

In Indonesia, the decentralization process, which started being implemented in 2001, aimed among other things to end corruption, collusion and nepotism (KKN: Korupsi, Kolusi dan Nepotisme) by empowering local governments across the country. However, decentralization reforms have not brought about the expected results. While the first objective was quickly achieved-villages and cities now enjoy greater responsibilities-transparency, accountability, and strong institutions are still lacking, imposing several challenges to the success of the decentralization process and hampering the fight against corruption.

Decentralization has introduced new actors and changed the modus operandi of corruption at the local level, increasing the opportunities/incentives for officials to behave corruptly. Local governments now enjoy wide discretionary powers and control over the application of more than $50 \%$ of the government budget, including over resources from mineral and timber, without having proper internal and/or external accountability mechanisms in place. These resources are transferred to local governments under a revenue sharing scheme, and they represent up to $80 \%$ of the total revenue collected by these jurisdictions. Local governments have also become responsible for basic infrastructure and the delivery of public services such as health, education, transportation, and agriculture, among others, which offers numerous opportunities for manipulation in the allocation of funds designated to such services. In addition, more than 2.5 million civil servants were reassigned to the district level government which have weak organizational structures and resources [2].

The introduction of local elections for mayors and city councilors brings another challenge to the control of corruption in the country. Reports have shown that the last local elections in 2009 were not free of frauds, with the manipulation of votes, mobilization of bureaucrats, intimidation 
of voters, and 'money-politics'. In addition, current political finance rules are inappropriate. The high costs of election campaigns have also encouraged candidates to seek support from the private sector or misuse public funds and resources. At the same time, regional election commissions which are responsible for overseeing the process were still ill-prepared to enforce the laws [4].

The Indonesian Corruption Eradication Commission, better known as the KPK (Komisi Pemberantasan Korupsi), is an extraordinary government law-enforcement body set up at the end of 2003 to fight extraordinary corruption that had become systemic and well entrenched in Indonesian life, affecting the lives and decision-making processes of practically everyone in the country, from the highest executive official to the lowest traffic police officer [10].

Table 1. KPK Corruptions Convictions

\begin{tabular}{lcccccccccc}
\hline \multicolumn{1}{c}{ Position } & 2004 & 2005 & 2006 & 2007 & 2008 & 2009 & 2010 & 2011 & 2012 & Total \\
\hline Parliamentary Members & 0 & 0 & 0 & 2 & 7 & 8 & 27 & 5 & 16 & 65 \\
Ministers/ Heads of & 0 & 1 & 1 & 0 & 1 & 1 & 2 & 0 & 0 & 6 \\
Minister Level & & & & & & & & & & \\
Ambassadors & 0 & 0 & 0 & 2 & 1 & 0 & 1 & 0 & 0 & 4 \\
Commissioners & 0 & 3 & 2 & 1 & 1 & 0 & 0 & 0 & 0 & 7 \\
Province Governors & 1 & 0 & 2 & 0 & 2 & 2 & 1 & 0 & 0 & 8 \\
Regent/City Mayors & 0 & 0 & 3 & 7 & 6 & 6 & 4 & 4 & 3 & 33 \\
Government Officials & 2 & 9 & 15 & 10 & 22 & 14 & 12 & 15 & 7 & 111 \\
Judges & 0 & 0 & 0 & 0 & 0 & 0 & 1 & 2 & 2 & 5 \\
Prosecutors & 0 & 0 & 0 & 0 & 1 & 0 & 0 & 2 & 2 & 5 \\
Private Sectors & 1 & 4 & 5 & 3 & 12 & 11 & 8 & 10 & 15 & 69 \\
Others & 0 & 6 & 1 & 2 & 4 & 4 & 9 & 3 & 2 & 31 \\
\hline Total & 4 & 23 & 29 & 27 & 55 & 46 & 68 & 41 & 47 & 340 \\
\hline \multicolumn{1}{r}{ Sourc: KPK (2012), cin }
\end{tabular}

Source: KPK (2012), cited in Control Risks Group Limited 2013- Anti-Corruptions in Indonesia)

At the same time, the majority of international companies seeking opportunities in Indonesia have pledged to comply with commitments to comply with strict extraterritorial anti-corruption legislation, including the US Foreign Corrupt Practices Act (FCPA) and the UK Bribery Act. While Indonesia's government has significantly improved measures to combat corruption over the past ten years, corruption remains a major impediment for foreign investment. According to global anti-corruption watchdog Transparency International (TI), perceptions of corruption in Indonesia are worsening. In the 2012 Corruption Perception Index, Indonesia was ranked at 118 (out of 180 countries, with the first country being the least corrupt). In 2011, Indonesia was ranked at 110. [10].

According to global anti-corruption watchdog Transparency International (TI), perceptions of corruption in Indonesia are worsening. In the 2012 Corruption Perception Index, Indonesia was ranked at 118 (out of 180 countries, with the first country being the least corrupt). In 2011, Indonesia was ranked at 110 [7]. Figures Indonesia has increased the level of corruption in 2009 than 2008. In 2009, Indonesia earned the nickname of the most corrupt of 16 countries based on survey Political and Economic Risk Consultancy , Ltd. Indonesia scored 8:32 corruption followed by Thailand (7.63), Cambodia (7.25), India (7.21) and Vietnam (7.11), Philippines (7.0). While, Singapore (1.07), Hong Kong (1.89), and Australia (2.4), occupy the top three cleanest countries, 
although there are allegations of cheating the private sector. While the United States ranks fourth with a score of 2.89 [11].

Corruption also seems to be pervasive at the local level according to the Indonesia Corruption Perception Index1 (Transparency International Indonesia, 2008). A majority of cities in the country score below the average of 4,42 (on a 0 , meaning more corrupt to 10 , clean, scale). The persistence of corruption is also reflected on the views of Indonesians' citizens on corruption. According to the Global Corruption Barometer (Transparency International, 2011), 43\% of the households surveyed believe that corruption has increased in the three years preceding the survey. The view on the effectiveness of the government's efforts to fight corruption is divided. $33 \%$ assessed it as effective and 35\% as ineffective. On a more positive note, the Integrity Survey conducted by the Indonesian Corruption Eradication Commission (KPK) shows an improvement of the average score on public sector integrity from 5.53 in 2007 to 6.31 in 2011 (on a scale from 0 , low integrity, to 10 , high integrity) [10].

According to Transparency International Indonesia the high costs of political campaigns leave no option for legislators and councilors at provincial and district legislatures but 'to abuse their power to seek funds to pay for their campaigns to win their legislative seats and to help finance their parties' activities'. Parliament and political parties are also perceived as highly corrupt. According to the latest Global Corruption Barometer, 52\% of Indonesians surveyed considered both Parliament and political parties as extremely corrupt. The culture of the secrecy within the national Parliament (i.e. close door meetings) also offers opportunities for corruption, and limits the ability of the press and public to monitor its proceedings [2], [4].

The fragility of the legal system in the state is so bare practice, how the elite of this country do not realize that their behavior can be witnessed by many people, who in earlier times , this kind of thing is very taboo to be known. Offense level of bureaucracy at the central and local elites have such a way that people doubted whether this country is really built upon laws be obeyed and treated similarly to the majority of the people. Criminal cases committed by members of the public (blue collar crime ) would not be as powerful as its message news KPK and the National Police or other bureaucratic elite.

Main causes of corruption in Indonesia [7]:

a. Structural factors. Cross-country studies which have attempted to identify common causes of corruption have focused on structural factors which often relate to lower levels of perceived corruption such as income levels, income inequality, openness to trade, and long exposure to democracy. Within this framework, it is expected that countries with high income levels (e.g. high GDP) will have lower levels of perceived corruption, or that, for example, countries which have been exposed to democracy for longer periods of time are also perceived as less corrupt;

b. Historical factors. Indonesia passed through many years of authoritarian regime ('new order' regime) when Suharto ruled the country surrounded by networks of patrons and clients. In exchange for support, Suharto ensured that his relatives, friends from the business community, and senior officials in the military were granted benefits such as monopolies, exclusive supply contracts, as well as tax breaks. The Bertelsmann Stiftung also considers that anticorruption, bureaucracy, and market liberalization reforms are being conducted at a slow pace because they pose severe threats to the oligarchic structures of old elites within the economic sector, and these old elites still play a significant role on national and local politics; 
c. Decentralization factors. Decentralization is considered by many scholars/development practitioners as an effective remedy in the reform of governance systems. However, to be effective, decentralization processes must not only empower local governments with increased resources and responsibilities, but also ensure that local governments are held accountable for the delivery of public services and use of public money. In this regard, if accountability is lacking or not existent decentralization may in fact create powerful incentives for local elites to capture resources and influence policy in their own interests rather than of the society as a whole, offering more opportunities for corruption to flourish.

\section{Government Public Relations and Bureaucracy Image}

The development of public relations as a science, art and practice over the years, more widely understood in developed countries, that is growing fast. The development of public relations and competition synonymous with the advancement of a company in the states adherents of liberal democracy, the market economy are free and competitive. Attention to the practice of public relations in the government bureaucracy, it seems to be recognized is still lacking, especially for developing countries with systematic transitional democracy such as Indonesia.

Globalization has thrust public relations into the limelight providing new opportunities while posing immense challenges as well. Whereas globalization has impacted the public relations industry in many ways, public relations also has contributed to the spread of globalization [12].

Why do voters support corrupt politicians? This question is of vital importance if it is believed that corrupt politicians are often widely popular and that corruption has a detrimental effect on development. The answer to the question shows that democracy is not necessarily a palliative to corruption and that reducing corruption may require political changes that go far beyond the administrative reforms of the "good governance" variety [13].

Massive corruption, as a form of abuse of power by the elite bureaucrats and politicians in the government, of course, resulted in bad image and reputation of institution. Likewise, the position of the government public relations officials are always faced with a difficult situation to do it's role, because of the position to be part of the bureaucratic system. Often the government public relations officer gets labeled as "fire brigade", just a spokesman for the agency, making clippings, press conferences, documentation and activities of the institution protocol.

In a bad climate because institutions imaging corruption, public relations officers has been unable to do image enhancement governmental agencies. Especially, if it faces elite bureaucrats involved in corruption, never a public relations officer who became a spokesman in front of journalists or the public. The existence and function of public relations in the government bureaucracy is not optimal and helpless in faces of rampant corruption.

Government public relations specialists-specially called public affairs officers in the United States and information officers in most other countries- are the critical link between the people and the government. The goals of Public Affairs in Government: The overall goals for government public affairs, regardless of the level, and to some extent, type of government, have at least seven purposes in common:

a. Informing constituents about the activities of government agency

b. Ensuring active cooperation in government programs-voting, curbside recycling, as well as compliance with regulatory programs-mandatory seat belt use, antismoking ordinances. 
c. Fostering citizen support for established policies and programs-census participation, neighborhood crime watch program, personal health awareness campaigns, support for disaster relief efforts.

d. Serving as the public's advocate to government administration-conveying public opinion to decision makers, managing public issues within the organization, encouraging public accessibility to administration officials

e. Managing information internally-preparing organization-focused newsletters, electronic bulletin boards, and the content of organization's internet site for employees.

f. Facilitating media relations-maintaining relationships with local press; serving as the organization's conduit for all media inquiries; educating the press on the organization, its practices, and its policies.

g. Building community and nation-using government-sponsored public-health campaigns and other public-security programs and promoting a variety of social or development programs. (Cutlip, at al, 2006)

Relationship between public relations and government, Stockwell (2009) states the four main ways in which PR intersects with democratic government:

a. The use of media management by government minder to pursue political objectives. I

b. The use of promotional techniques by government information offices to pursue policy Objective

c. The use of government relations techniques, including lobbying by corporations and interest group, to affect government policy and decision; and

d. The use of campaign techniques in the elections required to form government

The main functions of the central government public services in addition to information and communication between the agencies and the public, as well as the manager of a positive image and reputation of the institution, so that the support and participation of citizens is essential in carrying out government duties.

Smith [14] thoughts on the concepts related to reputation and image. Reputation is the general, overall, and long-term impression of an organization on a specific public. Based on how a public views and understands the organization, reputation thus is the prevailing impression of an organization and the social evaluation that people make of it. Reputation is rooted in what people know or think they know about an organization (the cognitive element) and what attitudes they hold based on that information (the affective element). Image is a more general and short-term evaluation of an organization's messages. It is drawn from the way an organization projects itself toward its various publics. Image is what people think about the organization based on the impact of its messages. Image is based on both word and deed - on the verbal, visual, and behavioral messages, both planned and unplanned, that come from an organization and leave an impression.

Image: A mental picture or idea produced from imagination or personality and presented by the public to/of a person, group or organization by others. Reputation: Notoriety or fame, especially for some specified positive or negative characteristic. Repute is the public estimation of a person or thing to be as specified, usually passive [12].

Public relations is the management function which evaluates public attitudes, identifies the policies and procedures of an individual or an organization with the public interest, and plans and executes a program of action to earn public understanding and acceptance [15]. 
Somerville [16] states in fact, it seems that almost every week public relations is pilloried for its role in contaminating and corrupting the political process in Britain. Spin doctoring, negative campaigning and the pernicious influence of lobbyists are all highlighted as examples of how public relations has degraded the political process. There are frequent calls to return to a type of political activity where somewhat dubious persuasive tactics had no place [17].

The IPR (Institute of Public Relations) addressed these concerns by extending its definition: Public Relations practice is the discipline concerned with the reputation of organizations (or products, services or individuals) with the aim of earning understanding and support. This is sometimes simplified further to: Public relations is about reputation - the result of what you do, what you say and what others say about you [17].

The Challenges of Government Public Relations. The development of information technology and public relations is fast and dynamic, certainly a challenge for the government's public relations officer. Challenges of the profession of public relations in government institutions are not only faced with improving the quality of human resources, also facing demands for transparency of budget management and the government bureaucracy. It, will be associated with the formation of citizen participation, the image and reputation of government agencies.

In Act 14 of 2008 article 1 paragraph (2), that "information is a basic requirement for the development of everybody and the personal and social environment is an important part of national security. Right to information is a human right and public disclosure is one of the important characteristics of a democratic country that upholds the sovereignty of the people to realize the good organization of the country. Public information is information generated, stored, managed, and delivered or received by a public body with regard to the organizers and the implementation of other public bodies in accordance with this Act and any other information relating to the public interest ".

Right to information is a human right and a public disclosure is one of the important features of a democratic country that upholds the sovereignty of the people to realize the organization of the state is good. Public information is information that is generated, stored, managed, delivered and or received by a public agencies relating to organizing and conducting any other public agencies in accordance with this Act and any other information relating to the public interest

Public agencies (Act No. 14/2008 article 1 paragraph (3) is the executive, legislative, judicial, and other entities whose functions and duties related to the conduct of the principal which most or all of their funds come from the state budget and/or budget area, or non-governmental organizations throughout part or all of their funds come from the state budget and regional budgets, community contributions, and/or abroad.

Elsevier (2008): These findings highlight the important role of government, which has the responsibility to build relationships with other countries. A government's role becomes more important as international relations and networks grow. Public relations, as one of the information subsidies, give a guideline to journalists and audiences to decide newsworthiness and develop a perception of events to achieve an organization's goal (Gandy, 1982). Government public relations directly and indirectly affect the country's credibility to other countries, and can cause an important gain or loss in political or economic relations with other countries. So the effectiveness of government public relations efforts is an important question, and this study posits an international news coverage gatekeeping model with newsworthiness and government public relations involvement as extra media influences [18]. 
Discourse of democratic governance based on the achievement of good governance and clean government. The phenomenon of people's demand for clean governance from corruption, depend on the establishment of professional governance, participatory, transparent, accountable, which was shaded by the certainty of the rule of law, accountability, responsiveness, efficient/ effective and far-viewed, as a form of commitment is very important.

Reform of bureaucracy at all levels of governance as a form of democratization, of course, would be a prerequisite for the growth of a more active participation, constructive and responsible. Discourse of democratization and regional autonomy (decentralization), it seems necessary to study that (1) how the linkage of economic, political, legal, military, and cultural change in nature, scope and capacity of state power took place, such as the ability challenged regulation and reduce in various fields, (2) how the relationship between the global and the regional circuits are political decisions and results (outcomes) between the state and its people, changing the nature and dynamics of national political systems of their own, (3) how the local groups, movement and nationalism doubt the existence of the state as the system of representative and responsible power. So the need for thought to consider how the practices, institutions, and organizations that already exist can be developed toward global democracy [19].

The existence of a government would not be sufficient only through the recognition of juridical legality without recognition and the active participation of their peoples. In this context, the PR government through technical guidance has been issued by the government are required to increase their skills, creativity and innovation in carrying out their duties, not stuck on the structures and hierarchies are rigid and stagnant. Without the courage to innovate and creative, public relations officer of the government is only complement the bureaucratic system that is considered very rigid and not creative.

Autonomy nation/state expressly limited to the global process, while at the same time shared sovereignty between national agencies, regional and international pluralism limited. Democratic government, will redistribute power between two different levels in order to improve the overall accountability of the agencies responsible for the administration and also provides a legal framework that guarantees democratic rights for all people. That the principle of autonomy which is the heart of democracy provides opportunities for everyone should enjoy the same rights (with the obligation of the same) in terms that evoke while restricting the opportunities that exist, that they are free and have equal rights to determine their own lives as long as not negate rights of others. The prospect of hope for the future lies in the valuable and urgent global civil society [19]"

Public relations government should be able to understand the various laws relating to all aspects of governance, especially the Act No. 14 of 2008 about Public Information Disclosure, as well as to understand the role of public relations in the organization of the state and society are required in the form: to seek, obtain, and provide the data or information regarding the organization of the state, and right to submit suggestions and opinion are responsible for the implementation of the state policy.

Elsevier Inc. [20]: Slangen and Mateusen [21] explicitly link government public relations with 'decided policies'. Slangen and Mateusen state that in the case of 'potential (not yet decided) policies' only press coverage generated by the minister or his/her spokesperson should be allowed. We think that the limitation of government public relations to only 'decided policies' is both unrealistic and may be unfortunate. Public sector organizations also have a need to ensure that government listens to their views, "but that it must be remembered that sometimes determined 
politicians do not want to hear strategic views from state organizations (Harris \& Fleisher, 2005, p. xxxiii). The public sector practitioner aims, however, to obtain, maintain and strengthen political support. This raises the issue of whether a public administration should serve as a vehicle for government propaganda or whether it is possible to separate politics from the administration [22]. There is a delicate balance between being a public servant and being a spin doctor.

Citizens participation in the organization of the state, as one relationship of mutual support in achieving the national development goals. All elements in the relationship between government and citizens have a role, functions and rights obligations should be assessed, managed synergistically to achieve a democratic system of government that is able to provide solutions and shared responsibility in implementing development programs based on the principles of good governance

Finally, public relations government officers should be able to understand and consider a few things: (1) Guarantee the rights of the public in obtaining information about governance, particularly with regard to local legislation, development planning, budget and finance areas, natural resource management/regional assets and public services; (2) Providing access to a broad and engaging people of national governance or regional; (3) Provide public complaints mechanism, the legal protection for the reporting and follow up.

\section{Conclusion}

The principle of autonomy that shapes the heart of democracy Provides opportunities for everyone to enjoy the same rights (in the same sense) in terms of increasing the opportunities for money that are available, they are free and have the same rights to determine the life they free the rights of others. To become an autonomous, integrated government, the government must be able to bridge and unify the various parts to increase the accountability of all existing parts and provide a legal foundation that provides merging rights for everyone. Law No. 14 of 2008 concerning Public Information Openness, and to understand the role of public relations in state and community organizations. Required, providing data or information needed and the right to be sent suggestions and asked to be responsible for implementing state policies.

As agreed, Slangen and Mateusen are "potential policies (not yet decided)" only press coverage produced by ministers or spokespersons is permitted. That opinion limits government public relations only to 'decided policies' must be changed. The interconnectedness of community organizations also has a need to ensure that the government changes as desired changes in civilization. Public sector practitioners support to obtain, maintain and support politics. This concerns the issue of public administration must be carried out as a vehicle for government propaganda and also possible to facilitate politics from administration, there is a complicated balance between being a public servant who attracts each other.

Supporting public awareness in the state is needed in the role, regulating and supporting, supporting synergy to achieve a government system that supports those who provide solutions and responsibilities in running the program. In addition to having to give permission to the public about governance, resources and assets, government instruments must also provide broad access from the region to the center. Completeness of public facilities is expected to be able to bridge the existing complement. 


\section{Reference:}

[1] P. Alford, "Jakarta rocked by justice chief Akil Mochtar's arrest for bribery," http://www.theaustralian.com.au/, 2013. [Online]. Available: http://www.theaustralian.com.au/news/world/jakarta-rocked-by-justice-chief-akilmochtars-arrest-for-bribery/story-e6frg6so-1226732545588\#sthash.JDNb8Xyw.dpuf.

[2] www.U4.no, "www.U4.no," $2013 . \quad$ [Online]. Available: http://www.u4.no/publications/corruption-challenges-at-subnational- level-inindonesia/\%0AUS Commercial Service, 2011. Doing Business in Indonesia.\%0A.

[3] S. Rose-Ackerman, "Political systems and corruption. 'Corruption: A Review,' In Jain, A. K. (ed.).," J. Econ. Surv., vol. special vo, no. Issues in New Political Economy, 1999.

[4] "Countries at the Cross-Roads: Indonesia," Freedom House, 2010. [Online]. Available: http://www.freedomhouse.org/report/countriescrossroads- 2010/indonesia.

[5] J. B. Dobski and D. Gish, The political Crisis of Liberal Democracy in Shakespeare and the Body Politic. United Kingdom: Lexington Book, 2013.

[6] A. K. Jain, "Corruption: A Review," J. Econ. Surv., vol. special vo, no. Issues in New Political Economy, pp. 71-121, 2001.

[7] "Control Risks," 2013. [Online]. Available: www.controlrisks.com.

[8] “Transparency International," $2013 . \quad$ [Online]. Available: http://www.transparency.org/home/browser.

[9] Nusantaranews, "No Title," 2010. .

[10] KPK, "Integritas Sektor Publik." [Online]. Available: http://www.kpk.go.id/53C368E66643-4F41-8CE3-5D367062E58/FinalDownload/DownloadId\%0AD2A2D9FEA301842395D504020871B76F/53C368E6-6643-4F41-8CE3-

F5D367062E58/uploads/PDdownloads/buku_integritas_sektor_publik_indonesia_2010.pdf $\% 0 \mathrm{~A}$.

[11] Vivanews, "No Title," 2009. .

[12] S. Oliver, Public Relations Strategy : a managerial approach. London and Philadelphia: Kogan Page Limited Sriramesh: Veřcǐc, cited in Elsevier Inc., 2007.

[13] K. Oskar, "'Why do voters support corrupt politicians?'In Jain, A. K. (ed.)," J. Econ. Surv., vol. special vo, no. Issues in New Political Economy, 2001.

[14] D. R. Smith, Strategic Planning for Public Relations- Updated Summer as a supplement. London: Routledge/Taylor and Francis Group, 2011.

[15] M. S. Cutlip, H. C. Allen H. Center, and M. G. Broom, Effective Public Relations. New Jersey: Pearson Education Inc. Upper Saddle River, 2006.

[16] I. Somerville, "Public relations, politics and the media. 'Corruption: A Review,"' J. Econ. Surv., vol. special vo, no. Issues in New Political Economy, 2001.

[17] A. Alison Theaker, The Public Relations Handbook. USA: Routledge, 2004.

[18] J. Y. Kim and S.-U. Yang, Effects of government public relations on international news coverage. Elsevier, 2008.

[19] K. Nash, Contemporary Political Sociology. USA: Blackwell Publisher, 2000.

[20] D. Geldersa and $\varnothing$. Ihlenb, Government communication about potential policies: Public relations, propaganda or both? Elsevier, 2009. 
[21] Slangen and Mateusen, Beyond agenda setting: Information subsidies and public policies. Norwood, NJ: Ablex Publishing Co., 2004.

[22] U. Rosenthal and A. Kouzmin, "Crisis and crisis management: Toward comprehensive government decision making," J. Public Adm. Res. Theory, vol. 7, no. 2, pp. 277-305, 1997. 